\title{
Chemistry in Senegal: Between Skepticism and Hope
}

\section{By Modou Fall, Serigne Amadou Ndiaye, and Mayoro Diop ${ }^{+}$}

$\mathrm{n}$ Senegal, the education and university system is characterized by the dominance of arts and humanities over science and technology. The practice of chemistry is relatively important regionally in universities (for both education and research), as well as in the industries-although with a strong contrast between these two areas. Will the dynamism of chemical associations and the recent discovery of gas and oil enable a change in the chemical sector in Senegal? Senegal is a country in West Africa with $\mathbf{1 5 . 3}$ million inhabitants where the practice of chemistry is quite established. In this article, we present the current state of chemical education, research, and industry, without forgetting, of course, the chemical associations that have become increasingly active in recent years.

\section{Chemical education \\ Secondary school}

The teaching of chemistry, which is an experimental discipline, aims to arouse a scientific vocation among its students as they acquire a body of knowledge that helps them to have a more complete vision of their environment and to be able to act on it while protecting its stability.

Throughout the curricula, students are trained to search for answers and analysis from various information sources (encyclopedias, textbooks, books, movies, videos, cassettes, the internet, etc.). During excursions, they visit factories and natural sites: water purification stations, drinking factories, power plants, etc. These activities facilitate an understanding of chemical applications and especially of the realities outside the classroom (e.g., problems of wastewater treatment, the food industry, or specific seasonal problems). Elements of the history of science are also taught, to emphasize the evolutionary character of knowledge and begin the first introduction to epistemology.

However, we note among Senegalese students a real distaste for science and technology. The director for Middle and High School Education of the Ministry of Education [2] reported on 10 December 2015, "We have now $32 \%$ scientists against $68 \%$ literary persons today, and we want to invert this trend at about 2025. For that purpose, it is necessary to take challenging measures and they were taken", he declared. Among these measures, we can list the increase of class time for scientific and technological subjects relative to those in the arts and humanities from the academic year 2014-2015, as well as the obligation for students in the 3rd year of high school to study physical sciences, which include physics and chemistry, from the academic year 2016-2017. Additionally, 20 new "scientific blocks" were constructed and equipped between 2012 and 2017, while 8 existing blocks were rehabilitated, according to the Minister in charge of Education [3]. These blocks are places of training and educational activities combining several middle schools. Four experimental disciplines are taught in these blocks, among which are physical sciences. Will these measures be enough to invert the trend by 2025? In the 2016 normal session for a high school diploma, 152575 candidates joined to participate in the test. Among these, only 32625 (21.4\%) were in science and technology. Girls represented $47.7 \%$ of the overall number. The global success rate was $43.3 \%$ in science and technology, compared to $34.7 \%$ for arts and humanities.

\section{Higher education}

The trend observed in high schools has also been observed in universities. According to the statistics, the faculties and students of scientific schools represent less than $25 \%$ of the total number of students. Chemistry is very often still coupled with physics, at least up to the Bachelor's degree. The LMD (Licence (i.e. Bachelor)-Master-Doctorate) system has been in effect since 2008, but the different credits counterbalance, so that a student can reach the Master's degree with a weak level in one subject or another (physics or chemistry).

Practical work in universities is threatened by the significant increase in the number of students. Universities are unable to ensure a suitable supply of chemicals and glassware. The Ministry of Higher Education, Research and Innovation (MHERI) regularly announces corrective measures, but these are sometimes quite slow to be implemented. This is the case with the announcement made on 10 July 2015 of the construction and equipment of 99 practical works laboratories in Universities and Higher Schools, of which 21 should be for chemistry.

Cheikh Anta Diop University of Dakar (UCAD) is the oldest of the five functioning Senegalese public universities. At its Faculty of Sciences and Technologies, there are four Master's degrees in chemistry: Physical Chemistry Applied to Energy and to Analysis, Chemistry and Biochemistry of Natural Substances, Molecular

+ This article was originally published in L'actualité chimique $n^{\circ} 412$ (November 2016) [1]. It is translated and updated here. 
to bilateral or international cooperation agencies-the main financing resulted from CAMPUS Projects (then CORUS projects), and, to a lesser extent for the chemists, from the Institute of Research for Development (IRD). Several apparatuses are now out-of-service for lack of adequate maintenance.

On the national level, the MHERI, through the Impetus Funds for Scientific and Technological Research (FIRST) and the Support Project for the Promotion of Women Teachers and Researchers (PAPES), grants an annual budget of up to 30,000 Euro to teams selected after calls for tender in predefined themes. These grants unfortunately do not leave much chance for basic research funding. These funds can allow the Senegalese chemist to acquire small equipment and consumables to make preliminary works, even to identify challenges of a research activity, but the results are generally not substantial enough for publication.

The ministry has, however, a big project, the Technical Support Platform for Emerging Research and Innovation (PATRIE). According to the ministry, this project will include "facilities and mutualized laboratories with very high levels of sophisticated equipment covering the domains of molecular and elementary chemical analysis, materials characterization, molecular biology, etc.". The ministry has already announced on 25 July 2016 the acquisition and installation of scanning and transmission electron microscopes and their accessories.

Additionally, access to scientific journals has been partially solved. The National Center of Scientific and Technical Documentation, under the supervision of MHERI, took out a subscription with Elsevier in 2015 concerning access to ScienceDirect and Scopus databases and to Masson and Cairn.info revues for the university libraries of the five public universities and the Polytechnic School of Thiès for three years (2015-2017).

For the moment, Senegalese chemists (the university teacher-researchers in particular) are obliged to move to European and, more and more, to North American laboratories for sophisticated analyses. In most of these cases, the chemist in question maintains excellent relations with this host laboratory, where he or she completed a PhD. Colleagues can welcome the Senegalese chemist in their laboratory, but cannot always assure accommodations, nor support the laboratory or other analysis expenses. The University Agency of the Francophone community often launched programs offering mobility scholarships, but these have dramatically decreased in number. On the other hand, universities in Senegal always grant "study trips" to their teachers and researchers every two years. Well
Skepticism and Hope

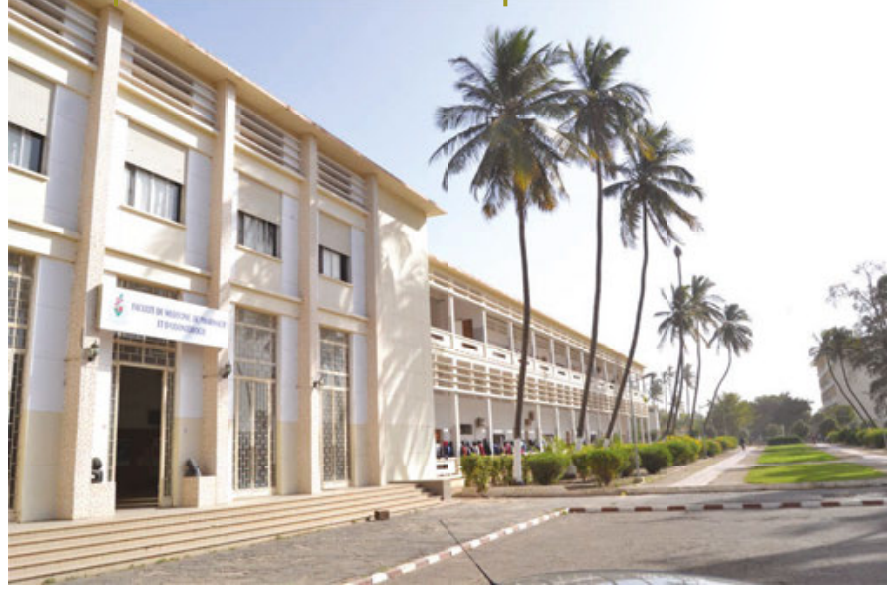

The Faculty of Medicine at UCAD

prepared, these study trips can allow chemists to complete work that is infeasible locally, work for PhD students, for example, or some advanced analyses needed to finalize an article.

\section{National Agency of Applied Scientific Research (ANRSA)}

ANRSA [4] works on the promotion of scientific research in Senegal, reflected in a new strategy termed "the innovation approach", a new orientation in the country's politics of scientific research. The agency is instrumental for the dissemination of new knowledge and for practical training of new techniques and technologies necessary for the development of innovative processes. These include bio-fertilizers and bio-pesticides production, fatty acids extraction, hot extraction of essential oil, preservation of fruits by vacuum dehydration, and biofuels production.

ANRSA also has several structuring programs, among which is the African Center of Research and Applications (CARA). The mission of CARA is to create a research environment congenial to scientific and technological innovation through the creation of science laboratories of high standards, well-equipped and endowed with adequate funding. The main objectives are to promote an endogenous development through the valorization of natural resources and the creation of research spaces and to provide monitoring services for microbiological quality of soils and water. Research centers will involve agricultural, food-processing, and medical biotechnologies, as well as the chemistry of natural products.

\section{Institute of Food Technology (ITA)}

ITA [5] is a scientific and technological public institution, at present placed under the supervision of the Ministry of Industry and Small Business. Its missions include quality control of processed foodstuffs 
and the coordination of research and studies dealing with the treatment, transformation, conditioning, preservation, and use of foodstuffs. ITA, which has been accredited by the United Nations University as a Reference Research Centre, has four modern laboratories for quality control: Chemistry, Microbiology, Mycotoxins, and Phytosanitary Analyses. The chemistry laboratory collaborates with universities and welcomes students preparing Master's degrees and PhDs. The laboratory of Mycotoxins and Phytosanitary Analyses has just been accredited (NF EN ISO/ CEI 17025) by the French Accreditation Committee (COFRAC) for aflatoxin assays.

\section{Research Institute for Development (IRD)}

IRD [6] has a Laboratory of Analytical Means (LAMA) in Dakar. This laboratory belongs to the Center for Instrumentation, Analytical Means, and Observation Stations in Geophysics and Oceanography (IMA$\mathrm{GO}$ ). The primary objective of LAMA is to support the research programs of the IRD, but it can also collaborate with other institutes or be requested by external customers. The LAMA of Dakar undertakes physicochemical analyses of soil, water, and vegetables.

\section{CERES LOCUSTOX Foundation [7]}

The Regional Center for Research in Ecotoxicology and Environmental Safety (CERES LOCUSTOX) is a recognized public foundation under the technical supervision of the Ministry of Agriculture. It has been accredited since March 2013 under number NF EN ISO/ CEl 17025 version 2005 (COFRAC) in Food-processing Industry/Diverse Food/Physicochemical Analyses. With this international recognition, CERES LOCUSTOX is recognized for reliability in the control of the contents of pesticides and other pollutants in agricultural products, as well as in the study of the effects of agricultural pesticides on the environment and on human and animal health. The Foundation also advises decision-makers and users on the rational use of pesticides and exporters on the promotion of the intrinsic quality of agricultural products, as well as training producers and agricultural companies on alternatives to chemical control.

\section{Industry}

Senegal possesses natural resources favorable to the development of the chemical industry. According to the Initiative for Transparency in the Mining Industries of Senegal (ITIE) [8], the country has significant geological potential, with a wide diversity of industrial minerals (phosphates, industrial limestones, baryte, etc.) and mineral substances, including precious metals (gold and platinum), basic metals (iron, copper, chromium, nickel), heavy minerals (zircon and titanium), decorative stones, and building materials, among others. But mining was until recently limited to phosphates, industrial limestone, and attapulgite. The exploitation of phosphates constituted an important pillar of the chemical industry, even of the entire Senegalese economy from the independence of the country in 1960 to the present. But mining activity has now become diversified through the development of the phosphates-fertilizers sector, the relaunching of the integrated project on the iron of Falémé, and the exploitation of gold in the region of Kédougou and of zircon and ilmenite (an ore used in the industry of pigments) in the region of Thiès. In the mining sector, Senegal granted a significant number of business licenses. Table 1 shows the quantities of some materials produced between 2009 and 2015.

The Directorate of Mines and Geology has placed a "Group of Analysis Laboratories" (GLA) in charge of chemical and mineralogical analyses for public and private companies, mostly in mining: chemical, geochemical and petrophysical analyses on mineral substances, industrial pollutants, and petroleum and derived products.

\section{Phosphates}

The exploitation of mine phosphates began in the 1950s with two big phosphate mines, Taïba and LamLam, in the region of Thiès. Recent explorations have been extensively led in other parts of Senegal. In the region of Matam, an important deposit of phosphates is at present exploited by the Research and Realization Firm of Phosphates of Matam (SERPM), with the aim of direct use in agriculture as fertilizer. In the zone of Thiès-Lam-Lam, there are important reserves of alumino-calcic phosphates recoverable in the sectors of natural fertilizers and animal feed.

The Chemical Industries Company of Senegal (ICS) [9], formerly the flagship of the chemical industry in Senegal, started their activities of phosphoric acid production in 1984. Phosphate, until then directly exported by the Senegalese Company of Phosphates of Taïba (CSPT), is now processed locally. In 1996, a merger between the ICS and the CSPT gave rise to the ICS Group, creating a vertical integration of the sector, from ore extraction to the production of phosphate fertilizers. 


\section{Chemistry in Senegal: Between Skepticism and Hope}

Beginning in 2001, a new investment policy resulted in the doubling of acid production and the opening of a new mine. One part of the production was moved offshore (to India for example), while the other part was done locally. Paradoxically, the company encountered difficult times and was about to close. The production of trade phosphate, which peaked at 1800 kilotonnes (kt) in 1999, dropped to $552 \mathrm{kt}$ in 2008, while the production of NPK fertilizers dropped from $200 \mathrm{kt}$ in 2002 to $51 \mathrm{kt}$ in 2008. A recapitalization in 2008 put important funding at the disposition of the company by its Indian buyer, but the situation hardly improved. The deficit of production and the debts of the company having reached a record level, a new recapitalization was decided upon in August 2014 and an Indonesian group took a majority interest in the capital of the ICS. Production has started again since then, but the government continues to import important quantities of fertilizer, resold to the farmers at subsidized prices.

\section{Industrial limestones [8]}

The Senegalese west central part of the sedimentary basin contains important resources in limestone and marno-limestone [8]. The eocene marno-limestones in Bargny, $30 \mathrm{~km}$ from Dakar, led to the creation of the first cement factory in Western Africa, SOCOCIM, in service since 1948. There are also important deposits of Paleocene limestone situated between Mbour in the South and Pout in the North. The second cement factory was opened in Kirène in 2002. An international cement group (Dangote) opened the third cement factory (of $2.5 \mathrm{Mt}$ ), which started its activities in Pout at the beginning of 2015 .

\section{Gold [8]}

Gold exploitation on an industrial scale began in the region of Kédougou. The production of the first gold ingot from the Sabodala mine, following a long process, was announced in 2009. In 2013, 25 research permits for gold exploration were granted to eight foreign companies and nine state-owned companies. In the South, the deposit of Sabodala, with important gold-bearing potential, was discovered in the zone of Massawa. Further east, along the border with Mali, interesting results were obtained in the zones of Guemedji. Craft mining activities are also increasing in this part of Senegal. However, their real scale is not known exactly.

\section{Heavy Minerals [10]}

Grande Côte Operation (GCO) [10] operates in the extraction of sands rich in heavy minerals, such as zircon, rutile, leucoxene, and ilmenite. The mine of Diogo, in the coastal zone in the North of the region of Thiès, has been under exploitation since 2014 . This exploration will be for a duration of 25 years and should produce $85 \mathrm{kt}$ of zircon, $15 \mathrm{kt}$ of rutile and leucoxene, and $570 \mathrm{kt}$ of ilmenite, making Senegal one of the largest world producers of these ores. The mine includes a dredge and wet concentrator and mineral separation plants. Another deposit of zircon was discovered in Niafourang in Casamance, but this exploitation is still hindered by a deep hostility of the people, who fear the destruction of their lands and other environmental disasters.

\section{Iron of Falémé [8]}

The iron deposit of Falémé consists of several heaps constituting altered ore enriched with martite and iron hydroxide. Deposits, located in four different

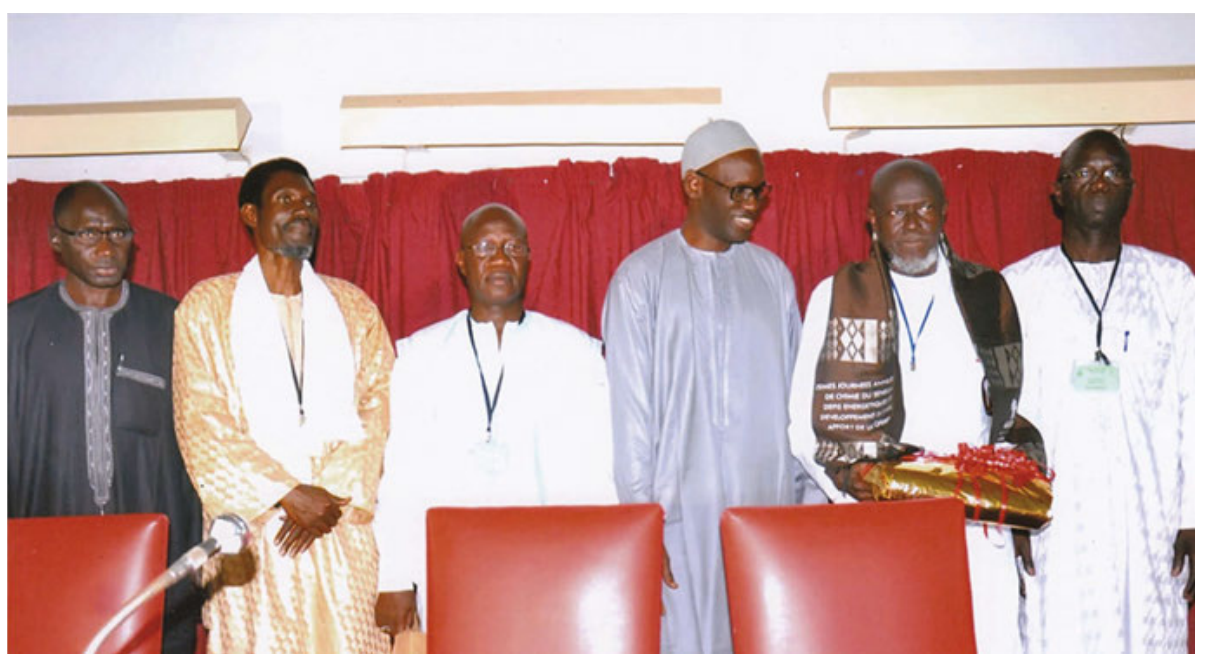

From left to right: Prof. Cheikh Bécaye Gaye, Director General of Research (MHERI); Prof. Abdoulaye Diop, President of SOACHIM-Sénégal; Prof. Serigne Amadou Ndiaye, President of CSC; Mr. Khadim Diop, Minister in charge of African Integration; Prof. Libasse Diop, Godfather of JACS 2016 with his gift and scarf; Prof. Matar Seck, President of the Organizing Committee of JACS 2016. 


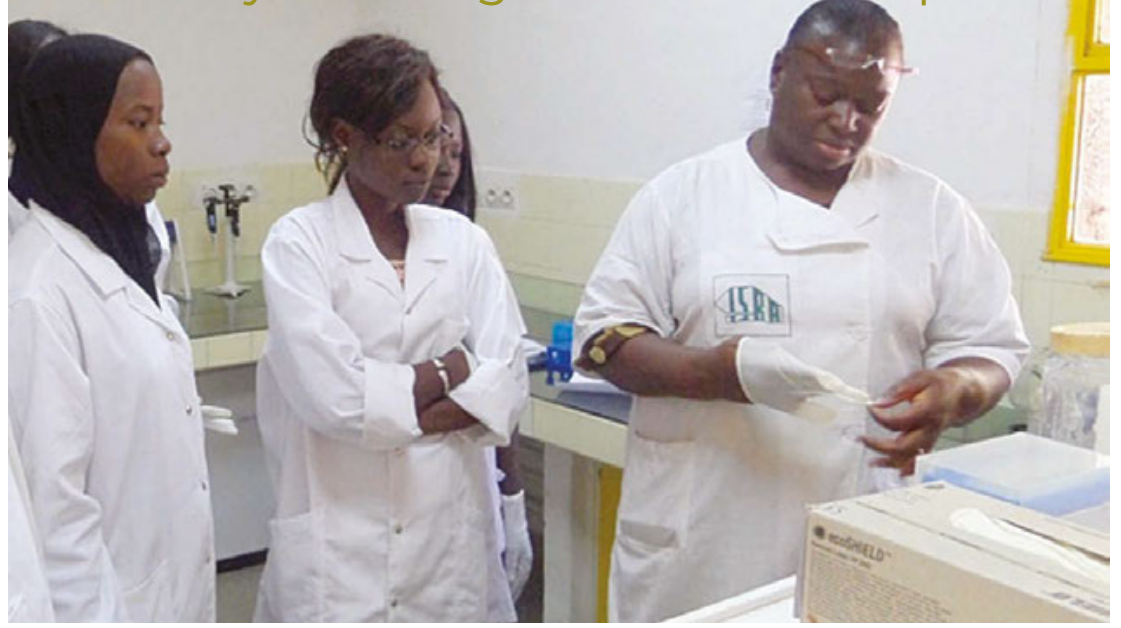

ISRA (Senegalese

Institute for

Agricultural Research),

in partnership with

universities, we/comes

students for training.

ISRA hosted the 3rd

edition of JACS 2018.

zones, are estimated at 750 million tonnes. A part of the production is intended for export and the rest for local use in support of the BTP (Building and Civil Engineering Works) industry.

\section{Hydrocarbons [8]}

In this sector, 11 research permits and two business licenses were granted in 2013 to a total of nine companies. The exploration and production of hydrocarbons (oil and gas) was performed across the Senegalese sedimentary basin. Recent works and studies have led to the identification of several prospects in deep offshore and in onshore areas. For oil exploration and production, the Senegalese sedimentary basin was divided into blocks and assigned to international oil companies as part of production-sharing contracts concluded with the government. Research confirms the existence of oil and gas in Senegal. However, on its whole basin, only one gas field is currently under production. The total gas production was $21 \times 10^{6} \mathrm{~m}^{3}$ in 2016, compared to $41 \times 10^{6} \mathrm{~m}^{3}$ in 2013 [8] and was used to produce electricity. In 2017, a series of oil and gas discoveries were announced by oil companies. One year before, in May 2016, the Senegalese government announced the discovery of natural gas deposits in the West of the country, with a capacity estimated at 140 billion cubic metres. Additionally, the government announced in January 2016 that an important natural gas deposit with reserves estimated at $450 \times 10^{9} \mathrm{cu}-$ bic metres was found in the North, at the border with Mauritania. In 2014, two discoveries were made of oil and natural gas in deep water off Sangomar after the drilling of two exploratory wells by an association of three oil companies and PETROSEN.

The government announced plans "to resolutely pursue the implementation of a convenient environment for the development of these hydrocarbons to favorably impact the whole economy in greater transparency." A Strategic Orientation Committee on Oil and Gas (COS-PETROGAZ) was created under the supervision of the Head of State. It is specifically in charge of assisting the President of the Republic and the Government in the "definition, supervision, evaluation and control of the implementation of state policy in the development of oil and gas projects in Senegal". Probably the main challenge for COSPETROGAZ is the opening of the National Institute of Petroleum and Gas, announced for the near future.

At least 11 oil companies were operating in the exploration and production of hydrocarbons in Senegal in 2014 [8]. In early May 2017, the French Group Total announced the signing of two agreements for exploration and exploitation of deep offshore oil concessions off the coast of the country. Just before, indeed on the same day, the Minister of Energy and Development of Renewable Energy, who disagreed strongly with the terms of these agreements, resigned from the government.

The exploitation is planned for at least three years. Will the African Company of Refining (SAR) be able to refine the oil to be produced? This is the oldest refinery in Western Africa, inaugurated in 1964 in Thiaroye, near Dakar. Expanding from 600000 tonnes per year in the beginning of its activities, the SAR's refining capacity now reaches 1200000 tonnes per year [12]. Since its creation, the company has supplied not only the domestic market in Senegal, but also the markets of bordering countries. Mali, Mauritania, The Gambia, Guinea, and Guinea Bissau are supplied with butane gas, high-octane gasoline, and regular gasoline, as well as fuel and diesel oil.

Last year, the Managing Director of SAR mentioned in the Senegalese press that the oil and gas discoveries have offered "the opportunity to revisit our dormant projects to consolidate our certainties". It is a question 
of endowing SAR with adequate facilities for its upgrade. There is first a project of expansion, which consists of enlarging the refinery to increase the annual production to three million tonnes. The construction of a new refinery and a "petrochemical complex" have also been evoked. The company would then have to comply with the standards of AFRI quality products promoted by the Association of the African Refiners (AAR), which establishes the reference regarding the quality of fuels in the region. It will require the creation of "desulfurization plants to respect the sulfur content in diesel oil and the ratio of benzene in gasoline."

\section{Food-processing industry}

In the food-processing domain, some major companies played a key role in the Senegalese economy, among which are the Senegalese Sugar Company (CSS) and the Company of Commercialization of Oilseeds (SONACOS).

The agro-industrial complex of CSS [13] produces refined sugar from sugar cane. This vertical process of manufacturing led CSS to be equipped with consequential means. The current annual production capacity of the factory should reach 150000 tonnes to meet the national need. The company is autonomous in energy: it exploits the cane residues (bagasse) as fuel in a steam boiler which, coupled with a power plant, not only supplies the necessary energy for the functioning of the industrial complex, but also for the city of Richard-Toll. Since 2008, CSS is also equipped with a distillery and is developing bioethanol production. The company also plans the extension of its cultivated surfaces, which requires the fertilization of plots of land subjected to a process of washing of soluble salts.

National Company of Commercialization of Oilseeds of Senegal (SONACOS-SA) [14] was formerly the first food-processing company of Senegal, the first Senegalese company of salad oils, and a world leader in the exportation of raw oil and peanut cakes. Its annual capacity of trituration is about 300000 tonnes of seeds hulls. The variety of peanut cultivated in Senegal is rich in oleic acid. Its average rate is between 55 and $70 \%$, which positions the peanut oil of Senegal as one of the richest oils in oleic acid after olive oil. Important efforts were made to reduce, and even to eliminate aflatoxin in the refined oil, but the company encountered difficult times, leading to privatization in 2007. Its name changed and became SUNEOR. The privatization failed, ending in 2015 with a separation between the majority shareholder of SUNEOR and the State of Senegal. The company became again SONACOS-SA and the State of Senegal is still looking for a buyer.

In addition to these "giants", food-processing companies of lesser scale exist in Senegal and are active

\begin{tabular}{|c|c|c|c|c|c|c|c|}
\hline Mineral substances (units) & 2009 & 2010 & 2011 & 2012 & 2013 & 2014 & 2015 \\
\hline Gold (tonne t) & 4.301 & 6.241 & 4.30 & 6.24 & 6.49 & 6.61 & 5.95 \\
\hline Silver (kg) & 539 & 670 & 0.54 & 0.67 & 0.85 & 1.15 & 0.54 \\
\hline Phosphate Alumina $\left(\mathrm{m}^{3}\right)$ & 17520 & - & 17520 & 12129 & 0 & 0 & 0 \\
\hline Phosphates of lime $\left(\mathrm{m}^{3}\right)$ & 111759 & 24881 & 1527759 & 1601373 & 1100000 & 1191944 & 1840980 \\
\hline Attapulgites $\left(\mathrm{m}^{3}\right)$ & 225331 & - & 225331 & 217443 & 220000 & 232379 & 229015 \\
\hline Marno-limestone $\left(\mathrm{m}^{3}\right)$ & 2839187 & - & 5567935 & 5591996 & 5671748 & 6398836 & 7177555 \\
\hline Limestone aggregates $\left(\mathrm{m}^{3}\right)$ & 450922 & 557585 & 450922 & 558100 & 570857 & 945032 & 2084256 \\
\hline Basalt $\left(\mathrm{m}^{3}\right)$ & 474110 & 263945 & 604097 & 801730 & 1188999 & 1638645 & 1627086 \\
\hline Clay (t) & & & 357149 & 329689 & 346660 & 422615 & 353923 \\
\hline Sand $\left(m^{3}\right)$ & 1279811 & 442162 & 1061383 & 810193 & 747413 & 949140 & 767088 \\
\hline Laterite $\left(\mathrm{m}^{3}\right)$ & 44547 & 54798 & 419054 & 831956 & 460029 & 221431 & 76469 \\
\hline Wills $\left(m^{3}\right)$ & & 1063 & 824 & - & 12605 & 430 & - \\
\hline Zircon (t) & & & - & - & - & 7167 & 41855 \\
\hline IImenite $(t)$ & & & - & - & - & 74924 & 420419 \\
\hline Rutile (t) & & & - & - & - & 162 & 1972 \\
\hline Leucoxene (t) & & & - & - & - & 0 & 2639 \\
\hline Manganese (t) & & & - & - & - & - & 6671 \\
\hline
\end{tabular}

Table 1: Annual Production of mineral substances in Senegal, between 2009 and $2015^{(9)}$. 


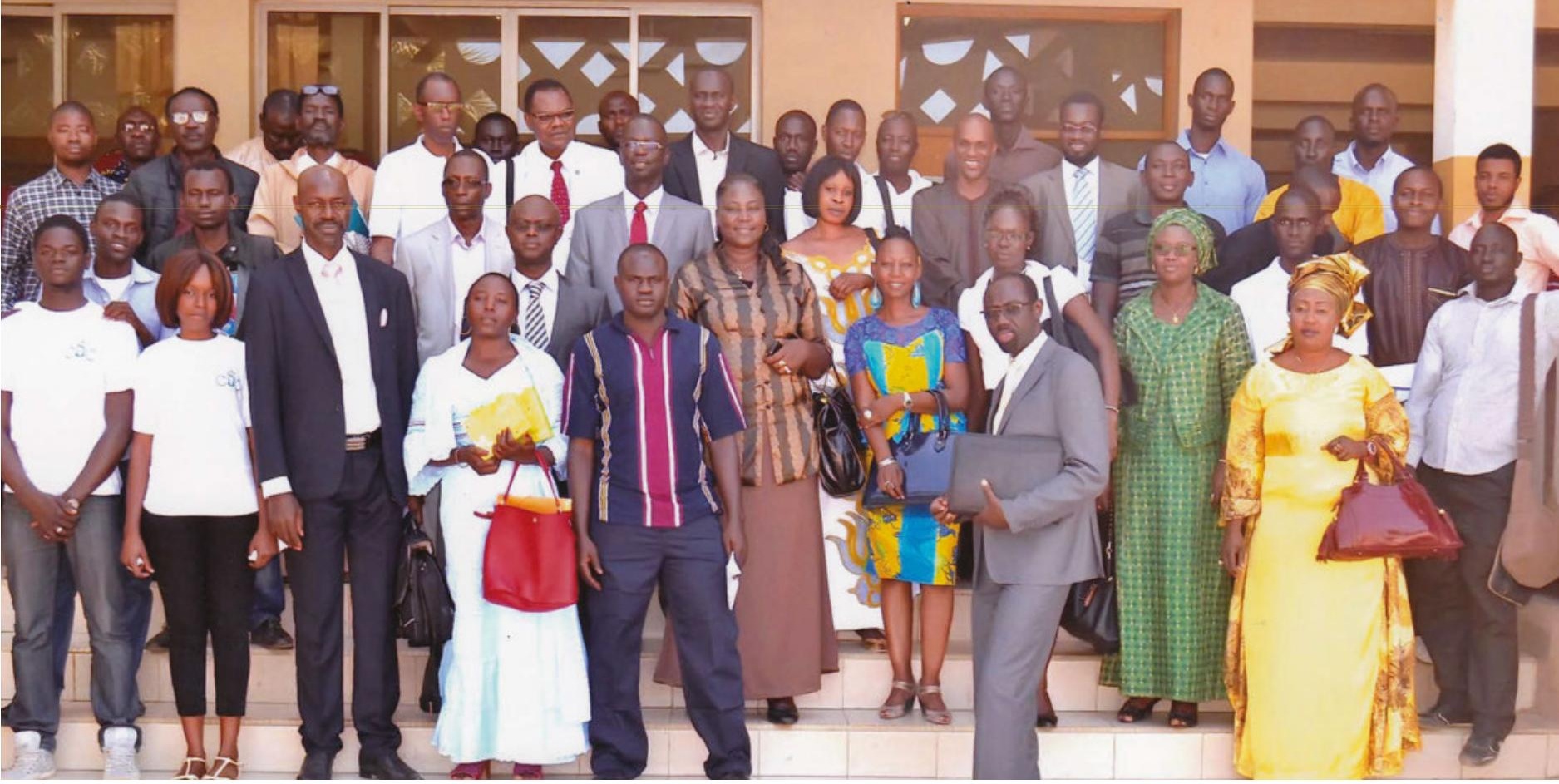

Pharmacopoeia, Medicinal plants of Western Africa: stakes and perspectives of development"' (26 April 2014 )

in the transformation of vegetables, fruits (e.g. drink, syrups, jam), the dairy sector, etc.

\section{Other chemical industries}

To support its development and its productivity, the chemical industry provides agriculture, not only with fertilizers, but also with pesticides. SENCHIM (Senegal Chemistry) [9], a commercial subsidiary of the Chemical Industries of Senegal, also has a production site for plant protection products located in Thiaroye, in the suburb of Dakar, capital of Senegal. SENCHIM offers Sub-Saharan African agriculture support through the provision of a complete range of products: seeds, fertilizers, pesticides, materials of treatments, etc.

Another big actor in agricultural chemistry in Senegal is located at Louga in the North of Senegal. It is the Company of Industrial and Agricultural Products (SPIA) [15]. It develops phytosanitary manufacture products for crop protection (fungicides, insecticides, herbicides, etc.) and for fighting against harmful species (disinfectants, etc.), as well as the treatment by fumigation or spraying of stored foodstuffs and places of storage. Today the company is present in all sectors of Senegalese agriculture (rice growing, truck farming, cotton, horticulture, arboriculture, etc.). SPIA also exports an important volume of its production to other African countries.

The paint industry sector is relatively developed in Senegal, where there are a half-dozen units of formulation: among them PPG Senegal, SENAC, and SAPEC, etc. which produce paints for the building, industry, the navy, automobile body, and more. There are also some representatives of foreign brands.

The pharmaceutical industry is also substantial in
Senegal. VALDAFRIQUE [16] is a leading player in the market of care and health products in West Africa. Big European groups and a Moroccan group are also located in the region of Dakar, among several other industries producing medicines, cleaners, cosmetics, etc.

\section{Laboratory of the Department of Internal Trade \\ (LCI) [17]}

$\mathrm{LCl}$ is a public institution with industrial and commercial character, certified ISO/CIS 17025V2005 (COF$\mathrm{RAC}$ ). It is related to the Ministry of Trade and Informal Sector and oversees food safety control and the preservation of the consumers' health. It is equipped with chromatographs and spectrophotometers for the dosage of vitamins, sweeteners, caffeine, histamine, conservatives, heavy metals, etc.

\section{Clubs and societies}

Senegalese chemists are grouped around two main associations: the West African Chemistry SocietySenegalese Section (SOACHIM-Senegal) and the Senegalese Committee for Chemistry (CSC).

SOACHIM-Senegal represents the West African Society of Chemistry (SOACHIM) at the national level [18]. SOACHIM was created by a general assembly on 4 February 1994 in Ouagadougou, Burkina Faso, by researchers and teachers in chemistry and biology from French-speaking West African universities. This sub-regional association mission is "gathering and creating a real synergy between people and institutions that are interested in the chemical sciences and their applications in the development processes of West-African countries" [18]. SOACHIM-Senegal participated 
in all annual meetings of the parent-society and welcomed the editions of 1996, 2006, and 2017 in Dakar.

The CSC [19] was created on 30 November 2013 on the initiative of teachers and researchers from national and international institutes and of chemists belonging to industry. Recognized by the state of Senegal on 2 April 2014, its main objectives are to popularize protocols and research results by organizing scientific events, to strengthen research facilities, to favor cooperation between universities, other structures of research, and chemical industries, and to adhere to the standards of international organizations dealing with chemical sciences.

The CSC organized a colloquium on the theme "Pharmacopoeia, Medicinal plants of Western Africa: stakes and perspectives of development" on 26 April 2014 (in its 1st year of existence). This colloquium was marked by the communication given by Professor Emmanuel Bassène of the Faculty of Medicine, Pharmacy, and Odontology of UCAD, who is specialized on Pharmacognosy, and that of Dr. Eric Gbodossou, renowned Senegalese traditional doctor. The latter made a plea for the focus on health through plants: "yesterday, the whole world ran after yellow gold, today, black gold calls the shots, tomorrow green gold (agricultural wealth) will manage the world. $90 \%$ of this agricultural wealth is in the third world and singularly in Africa", he exclaimed.

The CSC then organized the $1^{\text {st }}$ Annual Days of Chemistry of Senegal (JACS) on the theme: "Problematic of industrial and domestic waste treatment: role of the chemist" in Dakar on 17 and 18 November 2015. At the end of this event, the CSC proposed the creation of a National Laboratory of Environmental Analyses (LANANE) capable of making, in urgency, all samplings and appropriate analyses. The CSC is in search of partners for this project.

The $2^{\text {nd }}$ edition of JACS was organized in partnership with SOACHIM-Senegal on 25 June 2016. Professor Libasse Diop, who devoted 40 years of his life serving Chemistry in Senegal and Africa, was the godfather of the JACS 2016. The chosen theme (Energy challenges and sustainable development: the contribution of chemistry) and the current context, marked by the discovery of oil and gas in Senegal, led the Minister of African Integration and chair of the opening ceremony to invite Senegalese chemists "to play their part with perspicacity in this expanding configuration of hope, to hold their own and contribute to the creation of a clean industry."

The 3rd edition of JACS was scheduled for 18 and 19 June 2018. JACS 2018 were hosted by the ISRA (Senegalese Institute for Agricultural Researches) Research Pole in Hann (Dakar). On this occasion, 3 poster prizes awarded by IUPAC were foreseen. The theme was
"Chemistry, Agriculture and Sustainable Development."

Additionally, CSC represents the community of the chemists of Senegal in the International Union of Pure and applied Chemistry (IUPAC). Throughout the accession process, the CSC was supported by the French National Committee for Chemistry. In its role of National Adhering Member, the CSC took part in the 48 th IUPAC general assembly (6-13 August 2015) in Busan, South Korea. On this occasion, three members of the CSC were elected in 3 IUPAC divisions. The CSC representative in Division II (Inorganic Chemistry) participated in Brest in July 2016, during the 42 ${ }^{\text {nd }}$ International Conference in Chemistry of Coordination (ICCC 2016), in the process of attributing names and symbols for 4 new elements discovered in 2015. The CSC also took part in the 49 ${ }^{\text {th }}$ IUPAC general assembly (6-13 July 2015 ) in São Paulo, Brazil and plans to attend the $50^{\text {th }}$ general assembly in Paris in 2019.

\section{References}

1. M. Fall, S.A. Ndiaye, M. Diop, L'actualité chimique 412 (2016) 8-17.

2. www.actuprime.com/ecole-senegalaise-plus-desciences-de-technologie-et-moins-de-litterature-cacommence-en-4e-des-lan-prochain

3. http://news.adakar.com/h84914.html

4. www.anrsa.sn

5. www.ita.sn

6. www.imago.ird.fr/moyens-analytiques/dakar

7. http://cereslocustox.sn/

8. www.itie.sn

9. www.ics.sn

10. www.tizir.co.uk/projects-operations/grande-cotemineral-sands

11. www.dirmingeol.sn/pages_utiles/statistique_miniere. php

12. www.sar.sn

13. http://css.sn

14. http://fr.wikipedia.org/wiki/Suneor

15. www.spia-sn.com

16. www.valdafrique.com

17. www.commerce.gouv.sn/article.php3?id_article=173

18. www.soachim.org

19. www.csc.sn

Modou Fall <modou.fall@ucad.edu.sn> is Professor at the Cheikh Anta Diop University in Dakar, Senegal and Secretary General of the Senegalese Committee for Chemistry.

Serigne Amadou Ndiaye <asndiayel@yahoo.fr> is Professor at the Cheikh Anta Diop University in Dakar, Senegal, and President of the Senegalese Committee for Chemistry.

Mayoro Diop <mayorodiop2000@yahoo.fr> is Associate Professor at the Cheikh Anta Diop University in Dakar, Senegal and President of the Environment Commission of the Senegalese Committee for Chemistry. 